\title{
REMOVAL OF LOW CONCENTRATION OF KEROSENE FROM WATER USING NIPA PALM (NYPA FRUITICANS WURMB) FRUIT FIBRE
}

\author{
Adowei Pereware ${ }^{{ }_{1}} \boldsymbol{\Xi}$, Wariboko Edward ${ }^{1}$, Markmanuel Douye ${ }^{2}$ \\ ${ }^{* 1}$ Department of Pure and Industrial Chemistry, Faculty of Science, University of Port Harcourt, \\ Choba, Rivers State, Nigeria \\ 2 Department of Chemical Sciences, Faculty of Science, Niger Delta University, Wilberforce Island, \\ Bayelsa State, Nigeria
}

DOI: https://doi.org/10.29121/granthaalayah.v8.i6.2020.462

Article Type: Research Article

Article Citation: Adowei Pereware, Wariboko Edward, and Markmanuel Douye. (2020). REMOVAL OF LOW CONCENTRATION OF KEROSENE FROM WATER USING NIPA PALM (NYPA FRUITICANS WURMB) FRUIT FIBRE. International Journal of Research -GRANTHAALAYAH, 8(6), 1-9.

https://doi.org/10.29121/granthaa layah.v8.i6.2020.462

Received Date: 03 May 2020

Accepted Date: 22 June 2020

Keywords:

Kerosene

Chemical Oxygen Demand

Adsorption

Nipa Palm

\section{ABSTRACT}

Nipa palm fruit fibre was carbonized at $400 \mathrm{oC}$ in a muffle furnace and used to remove kerosene in contaminated water in a batch experimental process with chemical oxygen demand (COD) reduction as the measurement parameter. The elimination of kerosene in the contaminated water was studied by applying the effect of carbon dosage and initial contaminant concentration. The results obtained showed that, the best process conditions for removing kerosene in the contaminated water samples were $8.0 \mathrm{mg}$ carbon dosage at low concentration of $20 \mathrm{mg} / \mathrm{L}$ of kerosene contamination. The adsorption isotherm of the elimination process was evaluated by Langmuir and Freundlich isotherm models and the data fitted better to Freundlich isotherm $(\mathrm{R} 2=0.84)$ when compared to Langmuir isotherm ( $\mathrm{R} 2=0.88)$. The maximum monolayer surface coverage as computed from the Langmuir equilibrium adsorption data was $1.43 \mathrm{mg} / \mathrm{g}$. The overall outcome indicates that the carbonized carbon produced from Nipa palm fruit fibre has low ability in reducing kerosene from contaminated water.

\section{INTRODUCTION}

Oily by-products are the most commonly encountered water contaminants in the Niger Delta region of Nigeria due to incessant artisanal and small-scale refining of crude oil in the region (Horsfall and Abia 2003). These contaminants may be present in solution in emulsified form, dissolved, or floating films and they are capable of representing a substantial threat to almost all organisms living in the region of the polluted water bodies or areas. The four classes of oily contaminants found in contaminated waters are [1] light hydrocarbons; [2] heavy hydrocarbons; [3] lubricants and cutting fluid; and [4] fats that are found in both plants and animals. The light hydrocarbons include gasoline, kerosene and jet fuel. Kerosene which is one of the fractions obtained from fractional distillation of crude oil is an important heating fuel and the most frequently detected water contaminant in the Niger Delta region of Nigeria (Adowei et al., 2014; Isiuku et al., 2013) where drinking-water sources rely heavy on

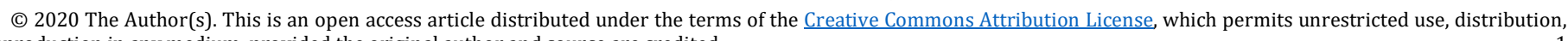
and reproduction in any medium, provided the original author and source are credited. 
Removal of Low Concentration of Kerosene from Water Using Nipa Palm (Nypa Fruiticans Wurmb) Fruit Fibre

borehole sources. Kerosene is a thin, clear liquid obtained from fractional distillation of petroleum between 150 $\operatorname{deg} \mathrm{C}$ and $275 \mathrm{deg} \mathrm{C}$, with typical density between 0.78 and $0.81 \mathrm{~g} / \mathrm{cu} \mathrm{cm}$. It is a mixture of aliphatic compounds with carbon chains usually between 6 and 16 carbon atoms per molecule. Consequently very stringent standards are required for the regulation of oily contaminants in drinking water and water meant for disposal.

Numerous standards and regulations were adopted for discharge of oily waste water into surface water or sewage systems. These regulations vary from one country to another, and even within a country itself. Environment Canada (1976b) established a discharge limit for oil and grease of $15 \mathrm{mg} / \mathrm{L}$ at Federal establishment. The allowable oil and grease concentration for discharge into water in Iraq is $10 \mathrm{mg} / \mathrm{L}$ (Sulaymon and Ali, 2010), while in Nigeria the allowable limit is placed at $10 \mathrm{mg} / \mathrm{L}$ (FEPA, 1996). However, due to frequent crude oil and hydrocarbon products pollution in the Niger Delta area, several boreholes in communities has been reported to contain oily sheen with kerosene like smell.

Hydrocarbon oily products possess a strong unpleasant odors, and even at low concentrations such water cannot be used for drinking or for industrial purposes. Hydrocarbons differ from other pollutants in that they can easily penetrate living tissues and accumulate in various body organs. Oil pollution also represents a threat to man as the hydrocarbons enter the body via water and food product. Therefore it is necessary to ensure that, no trace of oily product is found in drinking water. Analytical techniques for removal of these pollutants generally involve biological degradation, chemical oxidation, physical stripping and adsorption process (Prather, 1970). Adsorption techniques are widely used in the field of removing small quantities of pollutant present in the large volume of fluid, which can be carried out in batch-wise or continuous manner of operation (Rao, 1994). Adsorption is based on the preferential uptake of pollutants in the force field in adsorbent pores and it is effective throughout the concentration range for a dissolved pollutant, but its advantages are prominent most fully over other methods at low concentrations. Oil products dissolved in water are efficiently adsorbed by activated carbon, but their use are hindered by high cost. To reduce the cost of sorbents, often activated carbon from agro-wastes or non-useful biomaterials are employed.

In this research, a Nipa palm plant which at the moment is depleting the more useful mangrove trees in the Niger Delta was used to produce the adsorbents. The production of activated carbons from agro-wastes has potential economic and environmental impacts. First, it converts unwanted, low-value agro-waste to useful, high-value adsorbents. Second, activated carbons are increasingly used in water treatment to remove organic chemicals and metals of environmental and/or economic concern.

At the moment, there are very few studies (Adowei et al., 2014) on the use of activated carbon produced from different parts of the Nypa fruticans plant as adsorbent for removal of organic contaminant in aqueous solutions. In this paper we report the removal of kerosene in water contaminated with minute amount of kerosene using carbonized carbon made from Nipa Palm (Nypa Fruiticans Wurmb) Fruit Fibre in a batch adsorption process using chemical oxygen demand (COD) as the index of measurement.

\section{MATERIALS AND METHODS}

\subsection{SAMPLE COLLECTION}

Fresh fruit of Nipa palm plants were collected during low tide at the Ogbunabali waterfront along Eastern Bypass in Port Harcourt, Nigeria and taken for taxonomical identification. The Nipa Palm fruit were air dried and the fibre carefully removed. The fibre was oven dried at $80^{\circ} \mathrm{C}$ for several days, cut into small sizes, which were further oven-dried, grounded and sieved with a $150 \mu \mathrm{m}$ mesh size sieve to obtain the uniform sized biomass sample. The dried biomass sample was carbonized in Plant Science and Biotechnology Laboratory of the University of Port Harcourt, Nigeria.

\subsection{PREPARATION OF CARBONIZED CARBON FROM NIPA PALM FRUIT FIBRE}

$100 \mathrm{~g}$ of the sample was taken and weighed into a porcelain crucible. The porcelain crucible is then fixed into a muffle furnace, the adjustment knob was selected at a temperature of $400^{\circ} \mathrm{C}$ and the muffle furnace was left on for a period of $1 \mathrm{hr}$. The carbonized nipa fruit fibre was fixed in desiccators to cool so as to avoid air (so as to avoid oxidation from taking place). 


\subsection{PREPARATION OF SYNTHETIC KEROSENE CONTAMINATED WATER}

The following mixtures (in $\mathrm{ml}$ ) of kerosene: isopropanol ratios were made. 10:90, 20:80, 30:70, 40:60 and 50:50 made in five different $100 \mathrm{ml}$ volumetric flasks. The mixtures were thoroughly shaken by a shaker. The COD of these mixtures were measured as initial $\operatorname{COD}\left(C O D_{i}\right)$.

\subsection{BATCH ADSORPTION STUDIES}

\subsubsection{DETERMINATION OF EFFECT OF CARBON DOSAGE}

$2,4,6,8$, and $10 \mathrm{~g}$ of finely divided nipa palm fruit fibre with uniform particle size of 106 - $\mu \mathrm{m}$ were separately placed in a series of $75 \mathrm{ml}$ plastic sample containers containing $50 \mathrm{ml}$ of $100 \mathrm{mg} / \mathrm{l}$ concentration of kerosene solution. The suspensions were shaken at room temperature using agitation speed of $150 \mathrm{rpm}$ for $60 \mathrm{~min}$. At the end of $60 \mathrm{~min}$, Ten ml from each sample was taken and mixed with $10 \mathrm{ml}$ of iso-propyl alcohol (extra pure) as co-solvent (Bastow et al., 1997) and the mixture was shaken by the shaker (type: Stuart scientific, Auto vortex SA6, UK) for 2 min, and centrifuged at $1000 \mathrm{X}$. The COD of the clear supernatant solutions were determined by multi-parameter bench photometer with Tungsten light source at $420 \mathrm{~nm}$.

\subsubsection{DETERMINATION OF EFFECT OF INITIAL CONCENTRATION}

Solutions were prepared containing the desired kerosene concentration of 20, 40, 60, 80, and $100 \mathrm{mg} / \mathrm{L} .100 \mathrm{ml}$ of each prepared solutions were placed in plastic bottles each of $250 \mathrm{ml}$ capacity. $2.0 \mathrm{~g}$ of finely divided nipa palm fruit fibre with uniform particle size of $106-\mu \mathrm{m}$ were separately placed in the individual bottles with another bottle containing the same quantity of adsorbent and distilled water serving as a blank. The bottles were then placed on a shaker (Type: Stuart scientific, Auto vortex SA6, UK) and agitated continuously for $60 \mathrm{~min}$ at room temperature using agitation speed of $150 \mathrm{rpm}$. Ten $\mathrm{ml}$ from each sample was taken and mixed with $10 \mathrm{ml}$ of iso-propyl alcohol (extra pure) as co-solvent (Bastow et al., 1997) and the mixture was shaken by the shaker (type: Stuart scientific, Auto vortex SA6, UK) for $2 \mathrm{~min}$, and then centrifuged at $1000 \mathrm{xg}$ ).

The clear supernatant solutions were used for determination of COD using multi-parameter bench photometer (Model: HI 83099) with Tungsten light source at 420nm.

\subsubsection{PROCEDURE FOR MEASUREMENT OF CHEMICAL OXYGEN DEMAND (COD)}

$2.50 \mathrm{ml}$ centrifuged clear supernatant solution was added to the Reagent vials and $2.50 \mathrm{ml}$ of deionized water was added to another vial as blank. This was followed by slowly adding $2.50 \mathrm{ml}$ standard potassium dichromate digestion reagent and then mixed. Then a $3.5 \mathrm{ml}$ sulfuric acid reagent was added through the sides of the tubes and allowed to go down to the bottom. The content was capped and mixed and allowed to cool. The tubes were then transferred to the pre-heated COD digester at $150^{\circ} \mathrm{C}$ and digested for $2 \mathrm{hrs}$. Thereafter, each vial was inverted several times while still warm, they were then placed in the test-tube rack. The vials in the tube rack were left to cool to room temperature. At this point, there was no shaking or inversion so that the samples were not turbid. The concentration in $\mathrm{mg} / \mathrm{L}$ of oxygen demand was then measured for both blank and samples.

\subsubsection{ANALYSIS OF EXPERIMENTAL DATA}

The amount of kerosene removed from contaminated water at equilibrium by the biomass was calculated by the mass balance relationship (Adowei et al., 2015).

$$
q_{e}=\frac{\left.\left(C_{o}-C_{e}\right) V\right)}{w}
$$


Removal of Low Concentration of Kerosene from Water Using Nipa Palm (Nypa Fruiticans Wurmb) Fruit Fibre

Where

$q_{e}=$ amount of kerosene removed from contaminated water by carbon $(\mathrm{mg} / \mathrm{g})$

$C_{o}=$ initial concentration of kerosene contaminated water before contact with carbon

$C_{e}=$ equilibrium concentration of kerosene contaminated water after contact with carbon

$V=$ volume of kerosene contaminated water used (L)

$w=$ weight of the nipa fruit fibre carbon used $(\mathrm{g})$

The experimental data were analyzed by the two commonly used adsorption isotherm models of Langmuir and Freundlich.

The Langmuir equation is expressed as;

$$
\mathrm{q}_{\mathrm{e}}=\frac{q_{m} k_{L} c_{e}}{1+k_{L} c_{e}}
$$

Where $\mathrm{k}_{\mathrm{L}}\left(\mathrm{dm}^{3} \mathrm{~g}^{-1}\right)$ is a constant that is related to the adsorption/desorption energy, and $\mathrm{q}_{\mathrm{e}}$ is the maximum sorption on complete saturation of the adsorbent surface. Linearization of the above equation gives

$$
\frac{C_{e}}{q_{e}}=\frac{1}{q_{m} k_{L}}+\frac{c_{e}}{q_{m}}
$$

A plot of $\mathrm{C}_{\mathrm{e}} / \mathrm{q}_{\mathrm{e}}$ against $\mathrm{C}_{\mathrm{e}}$ gives a straight-line curve with slope $\frac{1}{q_{m}}$ and intercept $\frac{1}{q_{m} k_{L}}$.

The Freundlich isotherm shows the adsorption intensity of the adsorbate on the adsorbent and has a purely emprical formula

$$
q_{e}=\frac{x}{m}=k_{f} C_{e}^{1 / n}
$$

Where $\mathrm{q}_{\mathrm{e}}$ is the adsorption density ( $\mathrm{mg} / \mathrm{g}$ ), $\mathrm{x}$ is the adsorbed quantity ( $\mathrm{mg}$ ) $\mathrm{m}$ is the mass of adsorbent ( $\mathrm{g}$ ), $\mathrm{C}_{\mathrm{e}}$ is the concentration of the adsorbate in solution at equilibrium $\left(\mathrm{mg} / \mathrm{dm}^{3}\right), K_{\mathrm{F}}$ and $\mathrm{n}$ are the Freundlich constants.

According to Horsfall and Abia (2003), the value of $n$ shows the affinity of the adsorbate towards the adsorbent. The linearised form of the Freundlich equation is;

$$
\log \mathrm{q}_{\mathrm{e}}=\log \mathrm{K}_{\mathrm{F}}+1 / \mathrm{nlog} \mathrm{C}_{\mathrm{e}}
$$

If a plot of $\log q_{e}$ against $\log C_{e}$ yeilds a straight line, then the sorption process obeys a Freundlich adsorption isotherm. The $\mathrm{K}_{\mathrm{F}}$ and $\frac{1}{n}$ can be obtained from the intercept and slope of the straight line.

\section{RESULTS AND DISCUSSION}

\subsection{EFFECT OF CARBON DOSAGE ON THE REMOVAL OF KEROSENE FROM WATER}

The result obtained for the effect of carbon dosage on the removal of kerosene from the contaminated water using the carbonized carbon produced from the Nipa palm fruit fibre measured as percent removal of chemical oxygen demand (COD) is presented in Figure 1.

The data revealed that the percent (\%) COD reduction from the kerosene contaminated water as a result of carbon dosage were $36.84 \%$ for $2 \mathrm{mg} / \mathrm{L}$ carbon dosage, $51.06 \%$ for $4 \mathrm{mg} / \mathrm{L}, 56.06 \%$ for $6 \mathrm{mg} / \mathrm{L}$ carbon dosage, $66.44 \%$ for $8 \mathrm{mg} / \mathrm{L}$ carbon dosage and $61.65 \%$ for $10 \mathrm{mg} / \mathrm{L}$ carbon dosage respectively. The result showed that, COD reduction increased as the carbon dosage increased until a maximum reduction was obtained at $8.0 \mathrm{mg} / \mathrm{L} \mathrm{of} \mathrm{carbon}$ dosage. The maximum COD reduction observed for was $66.44 \%$.

The quantity of the adsorbent material to contact the adsorbate in aqueous solution has a significant effect on the adsorption process. Several authors (Kapadia et al., 2000, Tarawou et al., 2007) has revealed that, the larger the 
weight of the adsorbent, the greater the number of sorption sites available. This will increase the adsorbent porosity and surface area thereby enhancing the adsorption capacity due to the number of available adsorption sites.

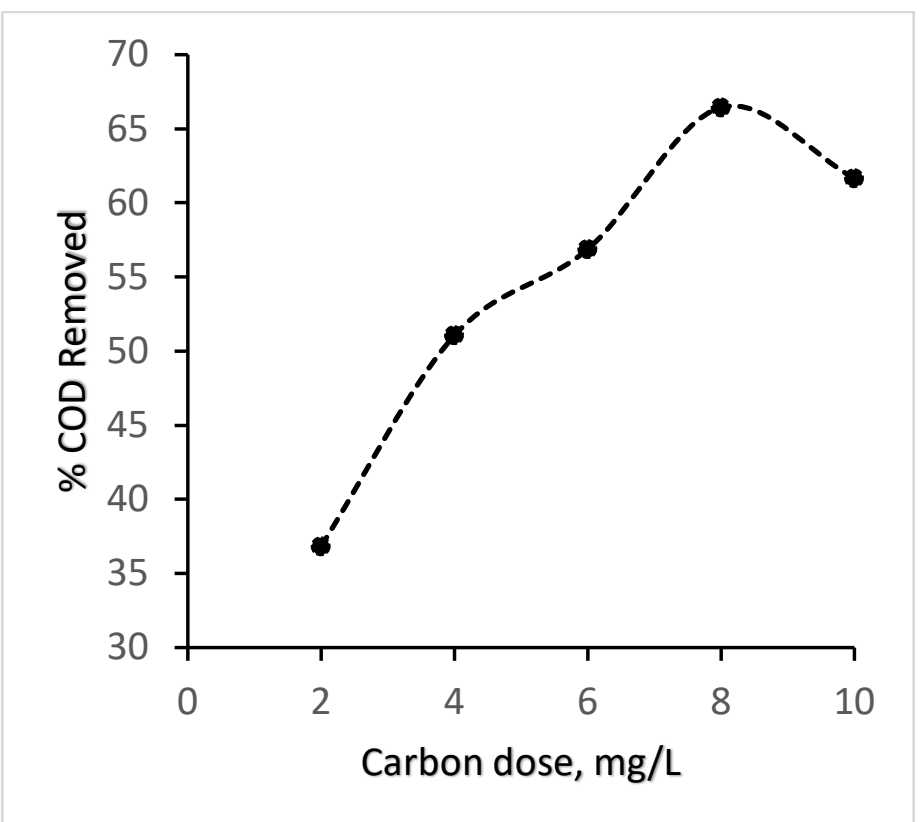

Figure 1: Effect of carbon dosage on COD reduction of kerosene contaminated water by carbon from Nipa palm fruit fibre

\subsection{EFFECT OF INITIAL CONCENTRATION ON KEROSENE REMOVAL FROM WATER}

The COD reduction capacity of the Nipa palm fruit fibre carbon for various initial concentration of kerosene in the contaminated water was also studied and the result is presented in Figure 2. The data showed that the ability of the sample to reduce COD is higher at lower concentration of kerosene contaminated water. From the figure, it was observed that, the percent of COD reduction which measures the adsorption efficiency of the carbons decreased with increase in initial kerosene concentration in the water. The reason may be that as the concentration of kerosene is increasing, the adsorption sites are easily taken up and more of the kerosene is unable to be removed.

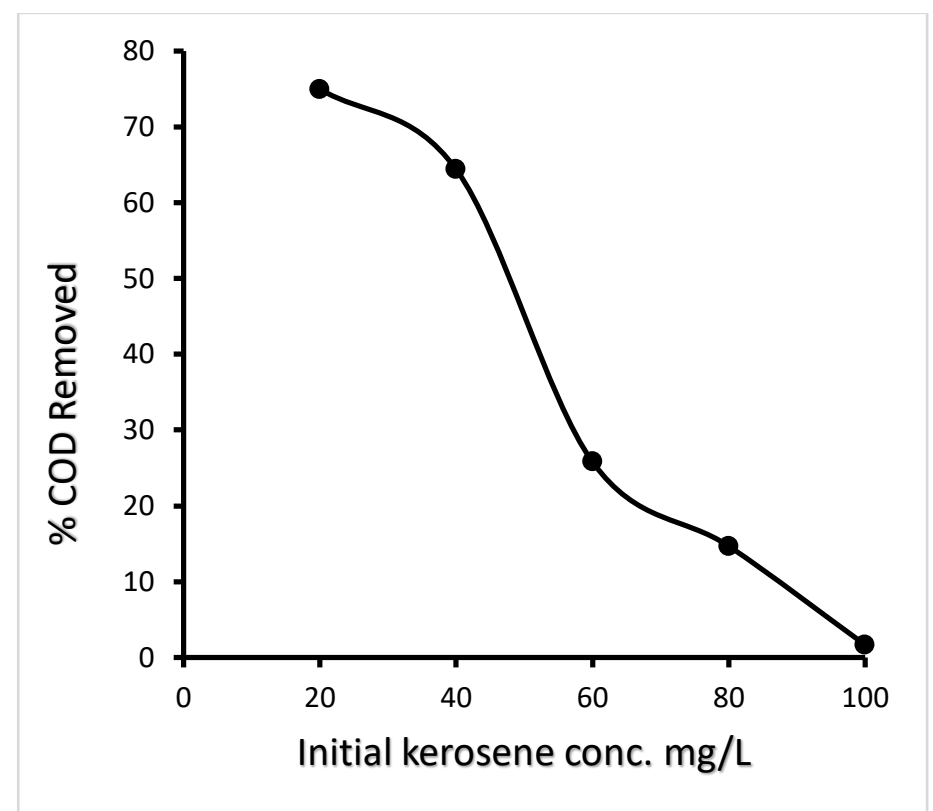

Figure 2: Effect of initial concentration of kerosene in contaminated water 


\subsection{ADSORPTION ISOTHERMS DATA ANALYSIS}

In order to estimate practical capacity, the COD reduction data obtained from the experiment were used to calculate the Langmuir and Freundlich model parameters. Langmuir equation was chosen to estimate maximum COD reduction capacity corresponding to monolayer coverage on the carbon surface. The sorption isotherms of COD reduction of kerosene contaminated water by Nipa palm carbon were fitted by the Langmuir and Freundlich models, as shown in Figure 3 and Figure 4.

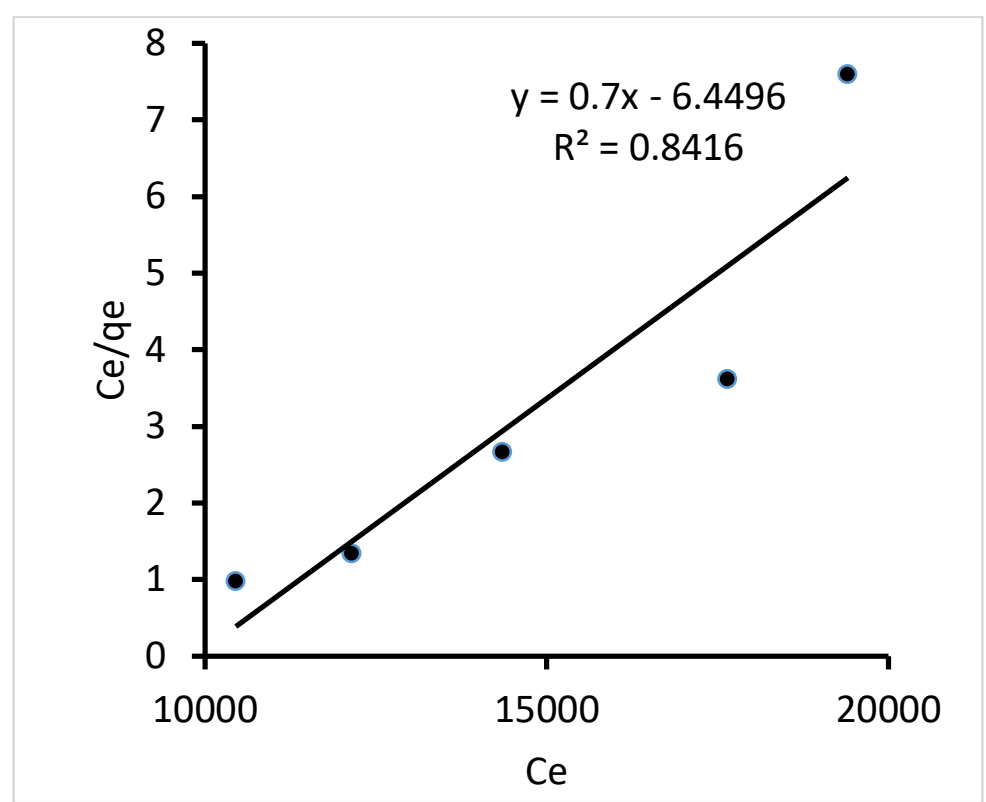

Figure 3: Langmuir isotherm model plot of COD reduction of kerosene contaminated water by carbon

The Langmuir constants $\mathrm{q}_{\max } \mathrm{K}_{\mathrm{L}}$ and the Freundlich constants $\mathrm{K}_{\mathrm{L}}$, $\mathrm{n}$ showed in these results were determined by linear regression and found to be 1.4286, 9.214 and $8.97 \times 10-7,5.14$ respectively and the regression coefficients ( $\mathrm{r}^{2}$ ) are 0.842 for Langmuir and 0.876 for Freundlich. These values suggest that the COD reduction of kerosene in contaminated water can be modelled by Langmuir as well as Freundlich model with a slight preference to Freundlich.

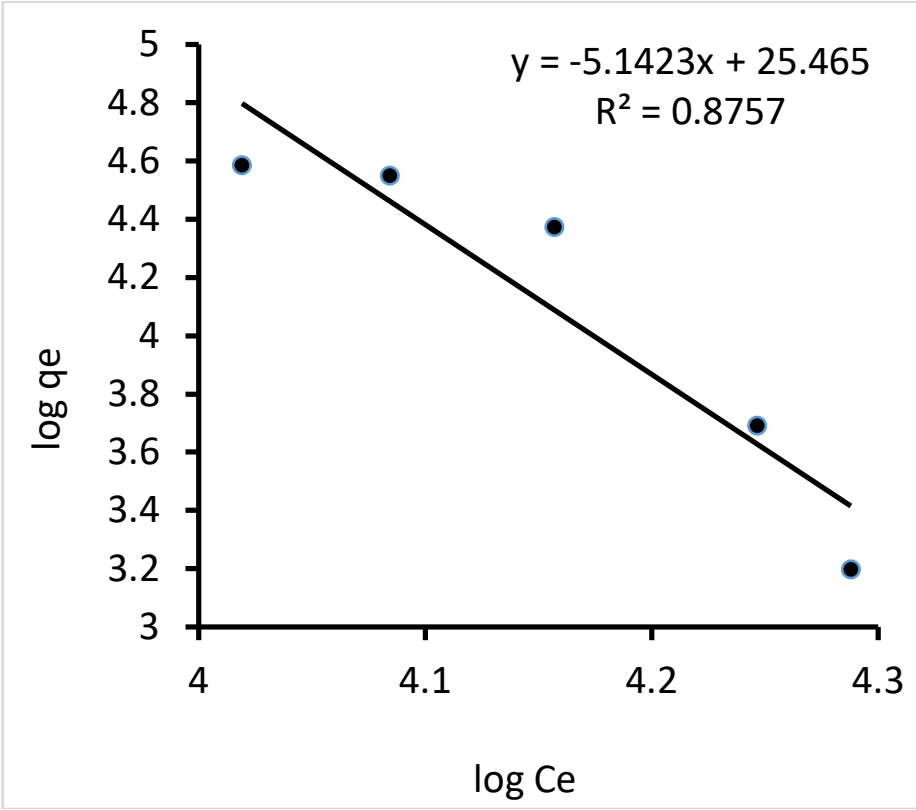

Figure 4: Freundlich isotherm model plot of COD reduction of kerosene contaminated water by carbon 
The values of the Langmuir parameters $\mathrm{q}_{\max }, \mathrm{K}_{\mathrm{L}}$ and Freundlich parameters $\mathrm{K}_{\mathrm{f}}, \mathrm{n}$ and the calculated regression correlation coefficients $\left(\mathrm{R}^{2}\right)$ were reported in Table 1.

Table 1: Langmuir and Freundlich isotherm parameters computed from the regression equations for COD reduction by Nipa palm carbon

\begin{tabular}{|c|c|c|c|c|c|}
\hline \multicolumn{2}{|c|}{ Langmuir Model Parameters } & \multicolumn{3}{c|}{ Freundlich Model Parameters } \\
\hline $\mathrm{q}_{\max }(\mathrm{mg} / \mathrm{g})$ & $\left.\mathrm{K}_{\mathrm{L}} \mathrm{L} / \mathrm{g}\right)$ & $\mathrm{R}^{2}$ & $\mathrm{n}$ & $\mathrm{K}_{\mathrm{F}}$ & $\mathrm{R}^{2}$ \\
\hline 1.4286 & 9.214 & 0.842 & 5.14 & $8.97 \times 10^{-7}$ & 0.876 \\
\hline
\end{tabular}

The Langmuir monolayer COD reduction capacity of Nipa palm biomass for methyl red in aqueous solution was estimated as $1.4282 \mathrm{mg} / \mathrm{g}$. Adowei et al. (2014) however, found that the COD reduction for some synthetic organic chemicals (SOCs) onto carbonized and surface-modified carbons produced from Nipa palm leaves followed Langmuir model. It can be seen that Nipa palm biomass is an effective adsorbent for the reduction of chemical oxygen demand (COD) for organic contaminants in aqueous solution, when compared with some other adsorbents.

The Langmuir data was further used to evaluate the favourability of the COD reduction process of methyl red solution by Nipa palm biomass. The dimensionless parameter of the equilibrium adsorption intensity $(R L)$ can be expressed as

$$
R_{L}=\frac{1}{1+K_{L} C_{o}}
$$

Where $\mathrm{C}_{\mathrm{o}}(\mathrm{mg} / \mathrm{L})$ is the initial concentration of the methyl red solution and $\mathrm{K}_{\mathrm{L}}(\mathrm{L} / \mathrm{mg})$ is the Langmuir constant related to the energy of adsorption. The value of $R_{L}$ indicates the shape of the isotherms to be either unfavorable $\left(R_{L}\right.$ $>1)$, linear $\left(R_{L}=1\right)$, favorable $\left(0<R_{L}<1\right)$ or irreversible $\left(R_{L}=0\right)$. The influence of isotherm shape on whether adsorption is favorable or unfavorable has been considered (Zacar and Engil, 2004). For a Langmuir type adsorption process, the isotherm shape can be classified by a dimension less constant the Separation factor $\left(R_{L}\right)$, given by the Equation above. The calculated $R_{L}$ value at an initial methyl red concentration of $100 \mathrm{mg} / \mathrm{L}$ was obtained as 0.097 . It was observed that this value of $R_{L}$ is in the range 0 - 1 which confirmed that there is a favourable removal of methyl red from the aqueous solution. The degree of favourability is generally related to the irreversibility of the system, giving a qualitative assessment of the biomass-methyl red interactions. The degrees of favourability in this study revealed that biomass-methyl red interactions is irreversible.

\section{CONCLUSION}

This study has successfully explored the equilibrium behavior of the production and application of carbonized carbon from Nipa palm fruit fibre for the removal of low concentrations of kerosene found in water samples from the Niger Delta region of Nigeria using reduction of chemical oxygen demand as the index of measurement. The study has provided data for the enlistment of carbonized Nipa palm fruit fibre as a potential and novel adsorbent for the reduction of low concentration of organic contaminates in water and may be recommended for industrial treatment of low hydrophilic organic effluents.

\section{SOURCES OF FUNDING}

None.

\section{CONFLICT OF INTEREST}

None. 
Removal of Low Concentration of Kerosene from Water Using Nipa Palm (Nypa Fruiticans Wurmb) Fruit Fibre

\section{ACKNOWLEDGMENT}

We acknowledged the support of the International Foundation for Science, (IFS), Sweden, with grant number W5574-1 to provide usefulness for the non-useful and evasive Nipa palm plant found in the Niger Delta region of Nigeria by converting into biocarbons.

\section{REFERENCES}

[1] Adowei, P. Spiff, A. I. and Abia, A. A. (2014). Evaluation of Carbonized and Surface-Modified Carbon Produced from Nipa Palm (Nypa FruiticansWurmb) Leaves for the Removal of 2-(N,N-Dimethyl-4-aminophenyl)-azobenzene carboxylic acid (DMABA) in Aqueous Solution ActaChim. Pharm. Indica: 4(3), 2014, 146-156

[2] Adowei, P. Spiff, A. I. and Abia, A. A. (2014). Evaluation of Carbonized and Surface-Modified Carbon Produced from Nipa Palm (NypaFruiticansWurmb) Leaves for the Removal of 2-(N,N-Dimethyl-4-aminophenyl)-azobenzene carboxylic acid (DMABA) in Aqueous Solution ActaChim. Pharm. Indica: 4(3), 2014, 146-156

[3] Adowei, P; A. I. Spiff and A. A. Abia (2014). Evaluation of Carbonized and Surface-Modified Carbon Produced from Nipa Palm (Nypa Fruiticans Wurmb) Leaves for the Removal of 2-(N,N-Dimethyl-4-aminophenyl)-azobenzene carboxylic acid (DMABA) in Aqueous Solution Acta Chim. Pharm. Indica: 4(3), 2014, 146-156

[4] Adowei, P; Abia A.A and Spiff A.I (2015). Physicochemical Characteristics of Biocarbons obtained from Nipa Palm (Nypa Fruiticans Wurmb) Leaves. Res. J. Chem. Sci. 5(1), 18-26

[5] Anisuzzaman, S. M;. Sariah Abang, D. Krishnaiah and Azlan N.A Removal of Used Motor Oil from Water Body Using Modified Commercial Activated Carbon Malaysian Journal of Chemistry, 2019, Vol. 21(1), 36-46

[6] Azouaou, N., Sadaoui, Z., Djaafri, A. and Mokaddem, H. (2010) Adsorption of Cadmium from Aqueous Solution onto Untreated Coffee Grounds: Equilibrium, Kinetics and Thermodynamics. Journal of Hazardous Materials, $184,126-$

[7] Boamah, P.O., Zhang, Q., Hua, M., Huang, Y., Liu, Y., Wang, W. and Liu, Y. (2014) Lead Removal onto CrossLinked Low Molecular Weight Chitosan Pyruvic Acid Derivatives. Carbohydrate Polymers, 110, 518-527.

[8] Chen, S., Yue, Q., Gao, B., Li, Q. and Xu, X. (2011) Removal of Cr(VI) from Aqueous Solution Using Modified Cornstalks: Characteristic, Equilibrium, Kinetic and Thermodynamic Study. Chemical Engineering Journal, 168, 909-917.

[9] Duran, C., Ozdes, D., Gundogdu, A. and Senturk, H.B. (2011) Kinetics and Isotherm Analysis of Basic Dyes Adsorption onto Almond Shell (Prunusdulcis) as a Low Cost Adsorbent. Journal of Chemical Engineering Data, $56,2136-2214$.

[10] Ekpete O.A. and Horsfall M. Jnr (2011). Preparation and Characterization of Activated Carbon derived from Fluted Pumpkin Stem Waste (Telfairia occidentalis Hook F). Research Journal of Chemical Sciences. Vol. 1(3) June 201110 - 17 www.isca.in, www.isca.me

[11] Ekpete, O. A; Horsfall M. Jnr (2011). Column Removal of Phenol and Chlorophenol Using a Commercial Activated Carbon. Adv. Environ. Biol., C(C): CC-CC, 2011, pp 1-7

[12] Ekpete, O. A; Horsfall, M. Jnr., and A. I. Spiff (2012). Kinetic of cholorophenol from adsorption onto commercial and fluted pumpkin activated carbon in aqueous systems. Asian J. Nat. Appl. Sci 1 (1) $106-117$.

[13] Ekpete, O.A; M. Horsfall Jnr and A.I. Spiff (2011). Fixed Bed Adsorption of Chlorophenol onto Fluted Pumpkin And Commercial Activated Carbon. Australian J. of Basic and Apl. Sci, 5(11): 1149-1155, 2011

[14] Foo, K.Y.; Hameed, B.H 2010 "Insights into the modeling adsorption isotherm systems (chemical engineering journal)

[15] Glossary of atmospheric chemistry terms (recommendations 1990). Pure and Applied chemistry 62: 2167.

[16] Glossary. The brownfieds and land revitalization technology support center. Retrieved 21-12-2009

[17] Horsfall, M. Jnr and Abia, A. A (2003). Sorption of Cd (II) and Zn(II) ions from Aqueous solutions by Cassava Waste Biomass (ManihotsculentaCranz).Wat. Res. 37: 4913 - 4923

[18] http://dx.doi.org/10.1016/j.cej.2011.01.063

[19] Isiuku, O.B., Horsfall, M., Spiff, A.I. (2013). Adsorption of metanil yellow on chemically-activated carbon in a packed-bed column: Effect of activation reagent. Journal of Engineering and Applied Sciences 8 (9) PP. 282 - 289 doi: 10.3923/jeasci.2013.282.289. 
[20] Joseph T. Nwabanne and Philomena K. Igbokwe, the thermodynamic and kinetic behaviours of Lead (II) adsorption on activated carbon derived from Palmyra palm nut, international journal of applied science and technology Vol. 2 No. 3, March 2012.

[21] Kapadia, M. K; Westheimer, G. and Gilbert, C. D (2000). Spatial Distribution of Contextual Interactions in Primary Visual Cortex and in Visual Perception. The American Physiological Society 2048-2062

[22] Mahvi, A; Maleki, A and Eslami, A (2004). Potential of rice husk and rice husk ash for phenol removal in aqueous systems. American Journal of Applied Sciences.14: 321 - 326

[23] Michael Horsfall Jnr. and Ayebaemi I. Spiff, journal of environmental biotechnology, Vol. 7 No 3, December 15, 2004.

[24] Rengaraje S, Moon, S H, Sivabalan, R, Arabindoo, B, Murugesan, V (2002). Agricultural solid waste for the removal of organics: Adsorption of phenols from water and wastewater by palm seed coat activated carbon. Waste Management Journal 2,: 543 - 548

[25] Tarawou, T; Wankasi, D; Horsfall, M (2007). Column Removal of methylene blue using activated carbon derived from water spinach (Ipomoea aquatic) Int. J, Biol. Chem. Sci Vol 4. No 3. 535 - 545

[26] Tarawou, T; Wankasi, D; Horsfall, M (2007). Column Reoval of methylene blue using activated carbon derived from water spinach (Ipomoea aquatic) Int. J, Biol. Chem. Sci Vol 4. No 3.535 - 545

[27] Ucun, H., Bayhan, Y.K., Kaya, Y., Çakici, A. and Algur, O.F. (2002) Biosorption of Phenol from Aqueous Solutionby Cone Biomass of Pinussylvestris. Bioresource Technology, 85, 155-158. http://dx.doi.org/10.1016/S0960-8524 (02)00086-X

[28] Uddin A. B., Helal M., Amat N., Ahmad S. and Mohd A. M. N, (2003). Effectiveness of peat coagulants for the removal of textile Dyes from aqueous "solutions and textiles wastewater. Malaysian Journal of Chemistry 5 (1) 034-043.

[29] Vinod, V. P; Anirudhan, T. S. (2001). Sorption of Tanic acid on zirconium pillard clay. Journal of Chemical Biotechnology 77: 92 - 101

[30] Zacar, M. O and I. A. S. Engil (2004), "Equilibrium Data and Process Design for Adsorption of Disperse Dyes onto Alunite," Environment Geology, Vol. 45, No. 6, 2762-768. 